\section{Research Article}

(C) 2020 Serpa et.al.. This is an open access article licensed under the Creative Commons Attribution-NonCommercial 4.o International License (https://creativecommons.org/licenses/by-nc/4.o/)

\title{
Contributions of Ivan Illich to Education in a Digital Society
}

\author{
Sandro Serpa \\ University of the Azores, Faculty of Social Sciences and Humanities, Department of Sociology; \\ Interdisciplinary Centre of Social Sciences - CICS.UAc/CICS.NOVA.UAc; \\ Interdisciplinary Centre for Childhood and Adolescence - NICA-UAc, Portugal \\ Corresponding Author

\section{Ana Isabel Santos} \\ University of the Azores, Faculty of Social Sciences and Humanities, Department of Education; \\ Interdisciplinary Centre for Childhood and Adolescence - NICA-UAc, \\ R. da Mãe de Deus, Ponta Delgada, The Azores, Portugal

\section{Carlos Miguel Ferreira} \\ ISCTE - University Institute of Lisbon, Av. das Forças Armadas, Lisbon, Portugal; \\ Interdisciplinary Centre of Social Sciences - CICS; \\ Estoril Higher Institute for Tourism and Hotel Studies, Portugal
}

Doi: 10.36941/ajis-2020-0o19

\begin{abstract}
Ivan Illich was a heavy critic of traditional schooling. His proposals were disregarded, perhaps too quickly, for various reasons. This paper, based on review research, aims to add to a current (re)reading of Illich, seeking to answer the following question: what is the relevance of Illich's proposal for a successful education in an increasingly digitalised society? The results of this research allow concluding, on the one hand, that Illich's proposal to replace strict schooling with (self)training networks in a society that is increasingly digitalised and linked by the internet may offer potential benefits, and it is worth, at least, of an in-depth analysis. On the other hand, provocative scholars that allow us to get out of any ideologically and socially delimited system have the merit of helping to provide instruments that enable a better understanding of the present and, consequently, a rationale for the options for the future. Ivan Illich is one of these scholars.
\end{abstract}

Keywords: Illich, deschooling, education, socio-educational intervention, digital society

\section{Introduction}

The school institution, seen as a codified and socially accepted way of responding to social needs (Serpa, 2018; Soegiono, Anis, \& Maulida, 2018) in the form of legitimate massive schooling, is undergoing a crisis (Gil \& Paniagua, 2016). Contrary to what it may seem, the School is a constructed reality and, thus, it is not inevitable (Queiroz, 2001). Furthermore, it has a specific culture, translated into ways of thinking and acting that are shared by a large number of people - the school culture (Serpa, 2016, 2018; Vincent, 1994).

In this sense, the School is one of the most relevant and influential institutions on social life 
(Varbelow \& Griffith, 2012). Its effects are profound. Perrenoud (2001), when reflecting on what the school does to families, and especially to the student, points out the following dimensions:

“a) his/her self-image, insofar that he/she internalised both the school's rules and the legitimacy of a judgment made about his/her conduct or competences;

b) his/her reputation with teachers, peers, parents, with what it has to be rewarding or devaluing;

c) his/her daily life in the classroom and at home, given that school excellence ensures some tranquillity, less heavy work, easier relationships with teachers, parents and even with classmates;

d) in the long run, success at the end of the school term, school year or study cycle; and the development of the school path, how it is managed by selection and guidance procedures;

e) in the longer run, the type and level of basic school education, qualifications and opportunities arising in the professional field" (p. 91).

In the $21^{\text {st }}$ century, the socialisation that took place in the school context - and, consequently, the School as a meritocratic institution, with a formal dimension that fosters the necessary competences for the overall development of the individual and his/her social action - is, demonstrably, at stake (Serpa, 2018).

We live in an increasingly digital society, in which technology is central (Gladden, 2019; Ferreira \& Serpa, 2018), with the consequent shifts at the micro, meso and macrosocial levels (Serpa \& Ferreira, 2019).

In this context, the need emerges to learn and apprehend diverse competences to be implemented in context. These competences may be specific or more transversal, such as autonomy, responsibility, social interaction, personal and professional development, leadership, communication, problem-solving, teamwork and creativity competences (Sá \& Serpa, 2018). According to the authors, this process

"[...] entails the involvement of the various stakeholders, with a higher focus on students and teachers, in a process that has to be explained and participated, involving formal learning but also non-formal and informal learning, in an integral logic of attainment and development of competences" (Sá E Serpa, 2018, p. 10).

As early as 1971, Ivan Illich sustained that "Work, leisure, politics, city living, and even family life depend on schools for the habits and knowledge they presuppose, instead of becoming themselves the means of education. Simultaneously both schools and the other institutions which depend on them are priced out of the market" (Illich, 2013, position 221). As Meyer and Rowan (1990) state, to Illich,

"The nature of schooling is thus socially defined by reference to a set of standardized categories, the legitimacy of which is publicly shared. As the categories and credentials of schooling gain importance in allocation and membership processes, the public comes to expect that they will be controlled and standardized. The large-scale public bureaucracy created to achieve this standardization is now normatively constrained by the expectations of the schooling rule. To a large degree, then, education is coordinated by shared social understandings that define the roles, topics, and contents of educational organizations" (p. 99).

However, if up to a certain extent - and as we will see later -, Ivan Illich offers several somewhat precursor aspects, he was, also and mainly, a heavy critic of traditional schooling. According to Enguita (2005), "Illich's work was, indeed, an accrual of errors, but they were not these, but rather an awkward success in their midst, which condemned him to disappear in the limbo of the righteous" (p. 129).

Coming from an author who is (was) "forgotten", there are many reasons why his proposals were, perhaps, too quickly disregarded and/or misinterpreted, notwithstanding, more recently and in a limited way, the emergence of some interest in the works of this thinker (Bruno-Jofré \& Zaldívar, 
2012; Inman, 1999). Indeed, we agree that "The history of the twentieth century pedagogy is incomplete without mentioning Ivan Illich's Deschooling Society" (Zaldívar, 2011, p. 618).

This essay, based on bibliographical research, aims to add to a current (re)reading of Illich, seeking to answer the following question: what is the relevance of Illich's proposal for a successful education in an increasingly digitalised society?

To fulfil this aim, this paper puts forth the methods used, followed by a re-reading of Ivan Illich's proposal, and finishes with the conclusions and implications of this reflection.

\title{
2. Methods
}

To answer the question that guides this research, a document collection and analysis was carried out at B-on (Biblioteca do Conhecimento Online), which allows Portuguese research and higher education institutions unlimited and permanent access to the full texts of many scientific journals, ebooks, reports, master's and doctoral dissertations and other publications (Biblioteca do Conhecimento Online, n.d.).

The selection of articles directly and explicitly related to the purpose of this review was based on a bibliographic collection that, in terms of articles, was carried out as follows: a search was made on B-ON for the term "Illich", either in the title or in the abstract, from 9 to 12 August. 165 and 463 articles, respectively, were obtained. These articles were analysed by title and abstract, and articles that directly addressed our research topic - which are listed in the references - were selected.

Next section offers a critical exposition of the mobilisation of Ivan Illich's critical stance on the alternative to school as a formal educational institution.

\section{A (re)reading of Ivan Illich}

As a framework for the analysis that follows, it seems relevant to consider that

\begin{abstract}
"When Illich approaches the study of contemporary society and its institutions, he makes a description from the outside, from a "naive" stance that helps him see the things that usually go unnoticed by habit and prejudice. His originality when studying the school institution, as when studying other contemporary institutions, stems from a descriptive-phenomenological approach that gives it acid and explosive innocence" (Santos Gómez, 2006, p. 184).
\end{abstract}

\subsection{Illich's view of the Educational Institution}

Ivan Illich (1926-2002) was a very well-known author, mainly in the 1970s, for his provocative publications, such as Deschooling Society (1971), where he proposed the eradication of the School as an institution (Illich, 2013/1970). This work, which caused, at the time it was published, deep waves of shock and criticism, but also a strangeness and, in some scientific and social swathes, even admiration (Hart, 2001; Daniels, 2003), is again mobilised due to its potential according to some authors (Narodowski \& Botta, 2017; Zaldívar, 2015).

This review does not aim to develop Ivan Illich's biography or bibliography. For that purpose, the reading of the following authors is suggested: Zaldívar (2011, 2015), Narodowski and Botta (2017), Kahn and Kellner (2007), Daniels (2003), Inman (1999); Samerski (2018), Saurén and Määttä (2011) and Pacheco (2013).

The role of Catholicism is critical to understand Ivan Illich's proposals. The thinker himself has been a Catholic priest (Santos Gómez, 2016; Bruno-Jofré \& Zaldívar, 2012):

"Toward the middle of the twentieth century, as the Church lost believers and the new faith in schooling became evident, the schools monopolized the possibilities of education in the same way that the Church had progressively come to dominate spiritual life in the Western world during the previous twenty centuries. His emphasis on this parallelism was such that he neglected the connections that schools and 
educational institutions have with their social, cultural, political, and economic contexts" (Bruno-Jofré, E Zaldivar, 2012, p. 586).

Through the School culture "as the shared way of being, thinking and acting in a collective of coordinated people with reciprocal expectations" (Serpa 2016, p. 51), the educational institution is considered, by the authors who are close to the theory of reproduction, as having the key purpose of perpetuating social and cultural differences (Valenzuela-Aguilera, 2008; Varbelow \& Griffith, 2012; Morrow \& Torres, 1997; Santos Gómez, 2006).

For Ivan Illich, in addition to reproducing social inequalities with the legitimation of inequalities, the School also functions as a "model of bureaucratic and class reproduction". The School justifies its own existence (the School) (Varbelow \& Griffith, 2012; Enguita, 2005; Santos Gómez, 2006, 2016; Zaldívar, 2015) through "formal rationalisation systems [that] have universal compulsive tendencies to reproduce at increasingly higher levels [...], although this process is also influenced and reinforced by social class antagonisms, generated in a great diversity of social formations" (Morrow \& Torres, 1997, p. 210).

In Deschooling Society (1971/2013), Ivan Illich greatly influenced Critical Pedagogy (Varbelow \& Griffith, 2012), by demonstrating (or, at least, trying to demonstrate) the ideological role of the School in this process of legitimate social reproduction (Zaldívar, 2015; Hardy, 2012; Valenzuela-Aguilera, 2008):

"The invisibility of the official learning centres or institutions allows them to remain immovable, and because of their nature as an institution that perpetuates hegemonic ideologies, they cannot be questioned (which does not mean that they cannot be transformed into certain historical situations). And that is indicated by Illich (1973), when he says that: 'The school has become untouchable because it is vital for the maintenance of the status quo"' (Valenzuela-Aguilera, 2008, p. 52).

In a synthesis, Ivan Illich proposes the need for a deschooling of society as a whole, valuing informal education. For Illich, the hidden curriculum is a critical element, also because it is not explicit or directly apprehended, about learning in a school context (Zúñiga Chaves, 2003; Topinka, Dočekal, \& Poslt, 2013).

For Illich,

\begin{abstract}
"A good educational system should have three purposes: it should provide all who want to learn with access to available resources at any time in their lives; empower all who want to share what they know to find those who want to learn it from them; and, finally, furnish all who want to present an issue to the public with the opportunity to make their challenge known." (2013, position 1361).

"But this would require that the educational revolution be guided by certain goals: 1. To liberate access to things by abolishing the control which persons and institutions now exercise over their educational values. 2. To liberate the sharing of skills by guaranteeing freedom to teach or exercise them on request. 3. To liberate the critical and creative resources of people by returning to individual persons the ability to call and hold meetings - an ability now increasingly monopolized by institutions which claim to speak for the people. 4. To liberate the individual from the obligation to shape his expectations to the services offered by any established profession - by providing him with the opportunity to draw on the experience of his peers and to entrust himself to the teacher, guide, adviser, or healer of his choice. Inevitably the deschooling of society will blur the distinctions between economics, education, and politics on which the stability of the present world order and the stability of nations now rest" (Illich, 2013, position 1859).
\end{abstract}

However, for this transformation into a deschooling process to happen and be successful "Illich's intention was to create an open, free, and independent learning circumstance, a learning environment without any discrimination or institutionalised restricted requirements in order to achieve inclusive education" (Soegiono et al, 2018, p. 260) -, a profound reformulation in the process of schooling, technology and attitude on the part of teachers is necessary, but not sufficient (Illich, 2013; Topinka et al., 2013). 
However, what is the relevance of Illich's proposal for a successful education in contemporary society, an increasingly digitalised society (Gladden, 2019; Ferreira \& Serpa, 2018)?

\subsection{The current (im)pertinence of the deschooling society}

For Illich, the purpose of his proposal would be "education for all means education by all" (Illich, 2013, position 471), in a logic "of a subject that is being through a construction process in common, with others, in the relationship with others" (Santos Gómez, 2016, p. 87), in respect for the human being's capacity to (re)create culture (Santos Gómez, 2016; May, 2015). In Ivan Illich's own words, in a long but enlightening quote,

"Educational resources are usually labelled according to educators' curricular goals. I propose to do the contrary, to label four different approaches which enable the student to gain access to any educational resource which may help him to define and achieve his own goals: 1. Reference Services to Educational Objects - which facilitate access to things or processes used for formal learning. Some of these things can be reserved for this purpose, stored in libraries, rental agencies, laboratories, and showrooms like museums and theatres; others can be in daily use in factories, airports, or on farms, but made available to students as apprentices or on off hours. 2. Skill Exchanges - which permit persons to list their skills, the conditions under which they are willing to serve as models for others who want to learn these skills, and the addresses at which they can be reached. 3. Peer-Matching - a communications network which permits persons to describe the learning activity in which they wish to engage, in the hope of finding a partner for the inquiry. 4. Reference Services to Educators-at-Large - who can be listed in a directory giving the addresses and self-descriptions of professionals, paraprofessionals, and free-lancers, along with conditions of access to their services" (Illich, 2013, position 1419).

Moreover, according to Narodowski and Botta (2017),

"The goals of the new and de-school educational institutions offered by Illich are three: (1) to promote access to educational resources throughout life, and not only in a childhood phase, (2) facilitate the meeting of those who want to share what they know with those who want to learn, removing bureaucratic hierarchies about knowledge and its certifications, and (3) generate opportunities to present and debate their arguments publicly. These institutions should be unrestricted access channels (in social, cultural, age terms), arranged according to their specificity, so that everyone has access to them" (p. 49).

For Illich, the deinstitutionalisation of society concurrently implies transformations and other social institutions, not limiting to the School (Inman, 1999; Pacheco, 2013; Bruno-Jofré, \& Zaldívar, 2012; Varbelow \& Griffith, 2012). On Illich’s proposal, Inman (1999) states that

"[...] he [Illich] proposed a more autonomous and organic organization of the learning process. This organization would reflect a new relationship between humans and their environment. One of these suggestions included an 'opportunity web' that allowed one to take advantage of experiences encountered in life. This web consists of four networks, each providing the learner with access to any educational resource one might find necessary to achieve individual goals. These include reference services to educational objects, skill exchanges, peer-matching, and reference services to educators-atlarge. These informal arrangements would provide learners with opportunities to draw on the experience of peers or to entrust themselves to a guide of choice. Either way, individual potential is realized outside institutional agendas" (p. 41).

For Varbelow and Griffith (2012), in their excellent and unavoidable article, "Illich was truly a visionary because what he describes is the availability of immeasurable learning and sharing opportunities through the World Wide Web" (p. 13). According to the authors,

"Illich tells us that the ultimate goal and the means to its accomplishment is the respect humans must have for one another. This respect can only be realized if we allow people to be and to become, which 
includes to allow and to entrust them to make autonomous decisions. It is the only way we can live life with integrity. It is these basic ideas of the humanistic responsibility one human being should have for another that must be the foundation for curriculum theory in the globalness of the 21st century" (Varbelow \& Griffith, 2012, p. 16).

However, the Internet also raises specific problems (Soegion et al., 2018; Marin, Masschelein, \& Simons, 2017; Gladden, 2019; Ferreira \& Serpa, 2018; Hart, 2001): "At a time when there is free access to a multitude of information, the knowledge society entails the development and mobilisation of a set of competencies of selection and application of this knowledge in a reasoned and conscious way" (Santos \& Serpa, 2017, p. 90 and 91). Alienation is one of these problems (Serpa, 2019). As maintained by Soegiono, Anis, \& Maulida, (2018),

"The idea of deschooling would enable everyone to use the self-directed learning method as a tool for learning. [...] These cognitive skills include the ability to gather and process information, as information overload is a common problem faced by self-directed learners. Thus, the challenge is to create a systematic design in the self-directed learning process which can accommodate 'weaker' people. In addition, digital learning has immense opportunities compared to conventional education in schools. However, it also has some major drawbacks in spite of its benefits. One of the greatest concerns regarding digital learning has always been a lack of social skills" (p. 267).

Ivan Illich's exposed stance is the subject of several criticisms, of which we highlight the one put forth by Enguita (2005), who argues that

"[...] a world without schools is, today, nothing more than an entelechy. Illich helped us open our eyes to the oppressive dynamics inherent in the school institution and the corporate interests of the profession, but without proposing any other answer than the impossible return to a non-existent past. It was not a utopia, but an ucronía. The task of those who believe another education is possible is not to imagine an implausible un-institutionalised world, but to democratise from top to bottom some institutions that we would not know how to do without" (pp. 135 and 136).

\section{Conclusion}

The schooling process is not necessarily equivalent to the development of literacy as the ability to process written information throughout an individual's life, in the most varied domains (Santos \& Serpa, 2017). According to Gil and Paniagua (2016),

"The school must be a place for the meeting and socialisation of ideas, where the generation of knowledge is prioritised without hierarchical purposes, but pleasurable pleasure and enjoyment, where it is not subject to strict dates and times, but that interest promotes continuous workdays, where the possibility of materialising real projects, necessary for a sustainable, aware and informed society and which is capable of making decisions, is shared and openly disseminated. Without regrets of what it is or yearning for what it could be, but rather building, participating, making inclusive and democratic decisions" (p. 31).

Ivan Illich, as one of the main authors of critical pedagogy, while ipsis verbis cannot be applied, provides very interesting instruments, both heuristic for understanding current schooling and society and for thinking and transforming this relationship (Zúñiga Chaves, 2003; Varbelow \& Griffith, 2012; May, 2015; Saurén \& Määttä, 2011; Bruno-Jofré \& Zaldívar, 2012). Inman (1999) sustains that

"Illich advocated not for the abolition of schools but rather for the end of their compulsion. Informal learning webs emerging from a free exchange of educational services were the preferred organization for learning within Illich's concept. It was the social organization of learning opportunities and the crushing mandates of an obligatory system to which Illich objected in the existing institutionalized version. He wanted each true being to have the ability to manifest itself" (p. 26). 
It is concluded, on the one hand, that Illisch's proposal to replace strict schooling with (self)training networks in a society increasingly digitalised and connected by the internet is likely to offer potential benefits, and it is, at least, worth of an in-depth analysis. On the other hand, provocative thinkers who allow us to leave the ideological and socially delimited system, have the merit of helping to provide instruments that enable us to better understand the present and, consequently, the options for the future. Ivan Illich is one of these thinkers who, both in 1971 and currently, still makes us think for his proposals (Aimino, 2018; Santos Gómez, 2006; Zaldívar, 2015; Daniels, 2003; Zúñiga Chaves, 2003), causing "half of admiration, half of irritation" (Daniels, 2003, p. 8o).

\section{Acknowledgment}

University of Azores, Interdisciplinary Centre of Social Sciences - CICS.UAc/CICS.NOVA.UAc, UID/SOC/04647/2019, with the financial support of FCT/MEC through national funds and when applicable co-financing from the FEDER under the PT2020 Partnership Agreement.

\section{References}

Aimino, M. (2018). El humanismo de Illich, evaluación de tecnologías para una sociedad convivencial [Illich's humanism, evaluation of technologies for a convivial society]. Tópicos. Revista de Filosofía de Santa Fe, 30, 118. doi: 10.14409/topicos.voizo.7714.

Biblioteca do Conhecimento Online (n.d.). What is b-on? Available at https://www.b-on.pt/en/what-is-b-on/. Accessed on Agosto 9, 2019.

Bruno-Jofré, B., Zaldívar, J. I. (2012). Ivan Illich's late critique of deschooling society: "I was largely barking up the wrong tree". Educational Theory, 62(5), 573-592. doi: 10.1111/j.1741-5446.2012.00464.x.

Daniels, A. (2003). Ivan Illich, 1926-2002. (Notebook). New Criterion, 21(5), 78-80.

Enguita, M. F. (2005). Nombrar lo innombrable, o lo difícil que resulta criticar el poder profesional - desde la profesión (a propósito de Ivan Illich) [Name the unnamable, or how difficult it is to criticise professional power - From the profession (on Ivan Illich)]. ETD - Educação Temática Digital, 6(2), 128-136. doi: 10.20396/etd.v6i2.778.

Ferreira, C. M., \& Serpa, S. (2018). Society 5.0 and social development: Contributions to a discussion. Management and Organizational Studies, 5(4), 26-31. doi: 10.5430/mos.v5n4p26.

Gil, E. C., \& Paniagua, R. L. (2016). Alternativas a la crisis de la institución escolar desde la pedagogía crítica [Alternatives to the crisis of the school institution from critical pedagogy]. IE Revista de Investigación Educativa de la REDIECH, 7 (12), 22-34.

Gladden, M. E. (2019). Who will be the members of Society 5.o? Towards an anthropology of technologically posthumanized future societies. Social Sciences, 8(5), 1-39. doi: 10.3390/socsci8050148.

Hardy, T. (2012). De-schooling art and design: Illich redux. iJADE, 31(2), 153-165.

Hart, I. (2001). Deschooling and the web: Ivan Illich 30 years on. Educational Media International, 38(2-3), 69-76. doi: 10.1080/09523980110041449.

Illich, I. (2013/1970). Deschooling society (I grandi dell' educazione). KKIEN Publ. Int. Kindle Edition.

Inman, P. L. (1999). An intellectual biography of Ivan Illich. PhD Dissertation, Illinois: Northern Illinois University.

Kahn, R., \& Kellner, D. (2007). Paulo Freire and Ivan Illich: Technology, politics and the reconstruction of education. Policy Futures in Education, 5(4), 431-448. doi: 10.2304/pfie.2007.5.4.431.

Marin, L., Masschelein, J., \& Simons, M. (2017). Page, text and screen in the university: Revisiting the Illich hypothesis. Educational Philosophy and Theory, 5o(1), 49-6o. doi: 10.1080/o0131857.2017.1323624.

May, A. (2015). Evaluating the use of "deschooled" methods in a postgraduate teaching assessment. Research in Post-Compulsory Education, 20(4), 434-444. doi: 10.1080/13596748.2015.1081748.

Meyer, J. W., \& Rowan, B. (1990/1976). The structure of educational organizations. In A. Westoby (Ed.), Culture and power in educational organizations (pp. 87-112). Philadelphia: Open University Press.

Morrow, R, A., \& Torres, A. T. (1997). Teoria social e educação. Uma crítica das teorias da reprodução social e cultural [Social theory and education. A critique of social and cultural reproduction theories]. Porto: Edições.

Narodowski, M., \& Botta, M. (2017). La mayor disrupción posible en la historia de la pedagogía moderna: Ivan Illich [The greatest possible disruption in the history of modern pedagogy: Ivan Illich]. Pedagogía y Saberes, 46. doi: 10.17227/01212494.46pys45.54. 
Pacheco, R. M. S. (2013). El pensamiento rebelde de Ivan Illich. Educación vs. Escolarización [The rebel thought of Ivan Illich. Education vs. schooling]. UIC. Foro Multidisciplinario, julio-septiembre, 38-43.

Perrenoud, P. (2001). O que a escola faz às famílias [What the school does to families]. In Montandon, C., \& Perrenoud, P. (Eds) (2001). Entre pais e professores, um diálogo impossível? Para uma análise sociológica das interacções entre a família e a escola [Between parents and teachers, an impossible dialogue? For a sociological analysis of the interactions between the family and the school] (pp. 57-112). Oeiras: Celta Editora.

Queiroz, J. M. de (2001). L'école et ses sociologies [School and its sociologies]. Paris: Nathan Université.

Sá, M., \& Serpa, S. (2018). Transversal competences: Their importance and learning processes by higher education students. Education Sciences, 8(3), 126. doi: 10.3390/educsci8030126.

Samerski, S. (2018). Tools for degrowth? Ivan Illich's critique of technology revisited. Journal of Cleaner Production, 197, 1637-1646. doi: 10.1016/j.jclepro.2016.10.039.

Santos Gómez, M. (2016). El soterrado cristianismo de Iván Ilich / The underground Christianity of Ivan Illich. Bajo Palabra, 12, 83-90. doi: 10.15366/bp2016.12.006.

Santos Gómez, M. (2006). Sociedad, utopía y educación en Iván Illich [Society, utopia and education in Ivan Illich]. Psicologia USP, 17(3), 183-201. doi: 10.159o/s0103-65642006000300012.

Santos, A. I., \& Serpa, S. (2017). The importance of promoting digital literacy in higher education. International Journal of Social Science Studies, 5(6), 90. doi: 10.11114/ijsss.v5i6.2330.

Saurén, K.-M. \& Määttä, K. (2011). New educational society. The Illich’s utophy. Pulso, 34, 29-42.

Serpa, S. (2016). An overview of the concept of organisational culture. International Business Management, 1o(1), 51-61. doi: 10.3923/ibm.2016.51.61.

Serpa, S. (2018). A reflection on Sociology of Education. International Journal of Social Science Studies, 6(3), 33-39. doi: 10.11114/ijsss.v6i3.3013.

Serpa, S. (2019). Alienation on social media. Studies in media and communication. 7, 17. doi: 10.11114/smc.v7i1.4286.

Serpa, S., \& Ferreira, C. M. (2019). Micro, meso and macro levels of social analysis. International Journal of Social Science Studies, 7(3), 120. doi: 10.11114/ijsss.v7i3.4223.

Soegiono, A. N., Anis, A., \& Maulida, S. R. (2018). Reconsider deschooling: Alternative towards more accessible and inclusive education. Masyarakat, Kebudayaan Dan Politik, 31(3), 256. doi: 10.20473/mkp.v31i32018.256-269.

Topinka, D., Dočekal, V., \& Poslt, J. (2013). The reproduction of social risks and social exclusion within the education system of the Czech Republic. Procedia - Social and Behavioral Sciences, 106, 3062-3068. doi: 10.1016/j.sbspro.2013.12.353.

Valenzuela-Aguilera, A. (20o8). Ivan Illich: True learning and the leisure pursuit of free people. Radical History Review, 102, 15-17. doi: 10.1215/01636545-2008-004.

Varbelow, S., \& Griffith, B. (2012). Deschooling society: Re-examining Ivan Illich's contributions to critical pedagogy for 21st century. 1-18.

Vincent, G. (Dir.) (1994). L'éducation prisonnière de la forme scolaire? [Education trapped in the school form?]. Lyon: Presses Universitaires de Lyon.

Zaldívar, J. I. (2011). Revisiting the critiques of Ivan Illich's deschooling society. International Journal for CrossDisciplinary Subjects in Education, 1(Special 1), 618-626. doi: 10.20533/ijcdse.2042.6364.2011.0087.

Zaldivar, J. I. (2015). Deschooling for all? The thought of Ivan Illich in the era of education (and learning) for all. Foro de Educación, 13(18). doi: 10.14516/fde.2015.013.018.005.

Zúñiga Chaves, J. F. (2003). Iván Illich: Hacia una desescolarización [Ivan Illich: Towards a deschooling]. Revista Electrónica Educare, 4, 49-6o. doi: 10.15359/ree.2003-4.4. 